\title{
Professor Kemp Malone
}

I $890-$ I 97 I

Den I3. oktober I97 I døde medlem af Grundtvig-Selskabets styrelse, professor Kemp Malone under et ferieophold i Eastport, Maine. Han blev 82 år, men var stadig fuldt beskæftiget med videnskabeligt arbejde.

Det var således hans hensigt ved sin tilbagekomst til Baltimore at afslutte et påbegyndt værk om det engelske sprogs historie.

Kemp Malone efterlod sig et forfatterskab inden for den engelske og germanske filologi, som omfatter over 500 afhandlinger. Blandt disse indtager hans studier over Grundtvig kun en beskeden plads, men som bidrag til Grundtvig-forskningen er de af stor interesse og væsentlig betydning. 3 af hans Grundtvig-afhandlinger: Grundtvig's Philosophy of History (1940), Grundtvig as Beowulf Critic (194I) og Grundtvig on Paradise Lost (I94I) blev indgående omtalt af Helge Toldberg i Grundtvig-Studier 1948, s. 98-102.

Det var også Toldberg, der bragte Kemp Malone i forbindelse med dansk Grundtvig-forskning under et af professor Malones besøg i Danmark, og som foranledigede, at Kemp Malone blev medlem af Grundtvig-Selskabets styrelse allerede ved selskabets start. Han forblev i øvrigt interesseret medlem lige til sin død, altså i 25 år.

Det var ligeledes Toldberg, som fik Kemp Malone til at offentliggøre sin af Toldberg til dansk oversatte afhandling om Grundtvigs oversættelse af Beowulf, Grundtvig-Studier i 96o, s. 7-25.

Det var et særkende for Kemp Malone, at han havde et åbent blik for den digteriske kvalitet af de gamle middelalderskrifter, som han fortrinsvis forskede i. En af hans kolleger har herom sagt, at ingen, som har lyttet til professor Malones brillante forelæsninger over oldengelsk poesi eller om Chaucer, kan nægte, at hans forskning har hjulpet tilhøreren til at forstå disse værker som poesi og ikke blot som skrevne ord, som man kunne gøre til genstand for dissekering. 
Denne holdning prægede også hans syn på Grundtvig, både historikeren og filologen. Bag hele Grundtvigs videnskabelige arbejde så han klarere end mange af sine samtidige digteren, den kristne digter.

$\mathrm{Vi}$ er mange inden for Grundtvig-Selskabets styrelse, som har haft den glæde at være sammen med Kemp Malone og nydt godt af hans meget store viden.

Professor Kemp Malone, der siden I92 I var tilknyttet The Johns Hopkins University i Baltimore (de sidste 30 år som professor i engelsk litteratur), og som efter sin afgang var visiting professor ved en stor mængder universiteter i Amerika og andre lande, kom også på besøg i Danmark. Det gav fra tid til anden en række danske Grundtvig-forskere lejlighed til værdifuldt samvær med en forskerpersonlighed, hvis lærdom var berigende og inspirerende, og hvis musiske sind og menneskelige varme måtte gøre et dybt og varigt indtryk på alle, der lærte ham at kende.

Grundtvig-Selskabet har ved hans død mistet et højt anset, internationalt agtet medlem, der har sat sig markante spor i Grundtvigforskningen, og hvis minde vi vil bevare med stor veneration.

Gustav Albeck 